> Tips om medisinsk litteratur, andre bøker, filmer og elektroniske medier som bør anmeldes, sendes tidsskriftet@legeforeningen.no

\section{En global velsignelse}

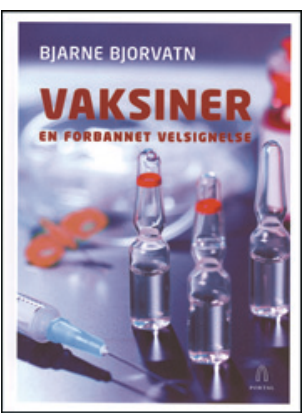

Bjarne Bjorvatn

Vaksiner

En forbannet velsignelse. 431 s, ill.

Kristiansand: Portal Forlag, 2015

Pris NOK 398

ISBN 978-82-8314-044-6

Vaksiner er omtalt av Verdens helseorganisasjon (WHO) som det mest kostnadseffektive medisinske tiltaket vi har i dag. Årlig reddes globalt 2-3 millioner menneskeliv som følge av vaksiner. Vaksinenes enestående effekt er også blitt deres akilleshæl. Yngre generasjoner har ikke opplevd de fryktede, smittsomme sykdommene, og oppmerksomheten skiftes fra vaksinens positive effekt til faren for ubehag og bivirkninger.

Bjarne Bjorvatn har skrevet en omfattende og god lærebok om vaksiner mot smittsomme sykdommer. Bjorvatn har lang klinisk og akademisk erfaring. Han er professor i medisin og spesialist i mikrobiologi og infeksjonsmedisin, og har vært konsulent i vaksineavdelingen i Verdens helseorganisasjon i perioden 1998-2013.

Vaksiner er skrevet på norsk, og undertittelen er treffende. Teksten er rik og lettlest og bærer preg av forfatterens imponerende kunnskap og personlige fortellerstil. Innholdet baserer seg delvis på offisielle dokumenter fra Verdens helseorganisasjon og refererer til disse samt publiserte fagartikler. Språket flyter godt og er allment tilgjengelig. Immunologikapitlet i starten er muligens eneste allmenne hindring, selv om fagbegrep konsekvent er forklart med norske ord. Her kunne det med fordel vært et par enkle illustrasjoner.

Boken er delt opp i 23 kapitler, en for hver vaksine, i alfabetisk rekkefølge. Innledningsvis gis en kort innføring i generell immunologi og vaksinologi og vaksinenes historie. Deretter er hvert kapittel delt opp i flere avsnitt som starter med et sammendrag. Siden følger utfyllende informasjon om epidemiologi, virologi/bakteriologi, patogenese, vaksinologi, anbefalinger fra Verdens helseorganisasjon og spesielle forhold ved den enkelte vaksinen. Kostnadseffektivitet og praktiske råd ved valg av vaksiner i ulike endemiske sammenhenger er også beskrevet. Kapitlene avsluttes med omtale av bivirkninger og påstander om alvorlige bivirkninger og den forskning som er gjort, og munner ut i en konklusjon. Til slutt er det en kunnskapstest som er egnet for å repetere innholdet $\mathrm{i}$ kapitlet. Boken er beskjedent illustrert, hovedsakelig i form av verdenskart, prevalensgrafer og enkelte kliniske bilder og virusillustrasjoner.

Målgruppen er studenter innen helsefag og andre med interesse for global forebyggende medisin, men boken har detaljer og bakgrunnsstoff nok til å tilfredsstille spesialiserte leger. Den er også egnet som oppslagsverk, og er et godt supplement til Vaksinasjonsboka, en veileder utarbeidet av Folkehelseinstituttet. Det beste med boken er at norske forhold settes i en global kontekst. I tillegg er det brukt mye plass på å gå nøye gjennom påstandene om alvorlige bivirkninger i ulike land, med påfølgende forskning og globale referanser knyttet til dette. Det gir denne utfyllende boken en ekstra dimensjon.

Vaksiner er en meget god lærebok, og jeg kan varmt anbefale

\section{Ny norsk lærebok om personlighetspsykologi}

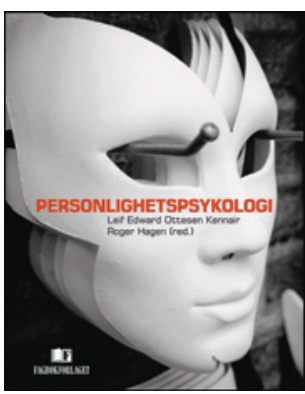

Leif Edward Ottesen Kennair,

Roger Hagen, red.

Personlighetspsykologi

386 s, tab, ill. Bergen: Fagbokforlaget, 2015.

Pris NOK 449

ISBN 978-82-450-1715-1
Personlighetspsykologi er en innholdsrik bok. Slik blir det gjerne når redaktørene samler 20 fremtredende fagfolk. Disse dekker fire hovedområder: det biologiske grunnlaget for individuelle forskjeller, de store personlighetsteoriene, helse og personlighet og anvendt personlighetspsykologi.

Kapitlene er grundige og formidler store kunnskapsmengder. Spesielt må jeg fremheve kapittel 2, Gener, miljø og personlighet, av Kristian Tambs, kapittel 4, En trekkteoretisk tilncerming til personlighet av Eva Langvik og Øyvind Lund Martinsen, kapittel 8, Personlighetstrekk i relasjon til psykisk og fysisk helse av Olav Vassend, kapittel 10, Personlighetsforstyrrelser av Svenn Torgersen og kapittel 11, Vitenskapelig måling av personlighet av Oddgeir Friborg.

Her, som ellers, er det en ulempe at det med mange forfattere blir mange gjentakelser. Spesielt gjelder dette femfaktormodellen. Grunntrekkene i denne gjentas om og om igjen.

Det er fire påtakelige svakheter. Den ene er dårlig og til dels manglende redegjørelse for temperament og emosjoner. Den andre er, pussig nok, en mangelfull redegjørelse om evolusjon og personlighet. Jeg skriver «pussig nok» fordi den ene redaktøren er en høyt profilert evolusjonspsykolog. Det evolusjonspsykologiske grepet i denne teksten har imidlertid utelatt primære emosjoner, som finnes hos alle pattedyr og som preger deres personlighet. Den tredje mangelen er at under hovedoverskriften Anvendt personlighetspsykologi finner man mye om rekruttering, ledelse og operativ psykologi, men ingenting om behandling av personlighetsproblemer. Det er heller ingenting om diagnostikk og personlighetsvurdering. Dermed blir ikke dette noen bok for klinikere - selv om det er kapitler om så vel psykoanalyse som personlighetsforstyrrelser. Det blir i hovedsak en bok for psykologistudenter, organisasjonspsykologer og folk som er spesielt interessert i akademisk psykologi. Den fjerde mangelen er at det ikke gjøres noe forsøk på å antyde en syntese eller peke på teoretiske og empiriske spenninger som kan ha implikasjoner for fremtiden. Av og til kan man få inntrykk av at spørsmålet om menneskelig personlighet er «løst», dvs. at femfaktormodellen utlegges som «sannheten». Litt mer kritisk sans hadde gjort seg. Femfaktormodellen har åpenbart god prediktiv validitet på en del områder, men overordnet sett er det ikke bare denne anmelderen som ser den som en ganske stusselig teori om menneskelig personlighet.

Sigmund W. Karterud

Professor i psykiatri, Seksjon for personlighetspsykiatri Oslo universitetssykehus 